\title{
KCNK18 wt Allele
}

National Cancer Institute

\section{Source}

National Cancer Institute. KCNK18 wt Allele. NCI Thesaurus. Code C94675.

Human KCNK18 wild-type allele is located in the vicinity of $10 q 25.3$ and is approximately $13 \mathrm{~kb}$ in length. This allele, which encodes potassium channel subfamily $\mathrm{K}$ member 18 protein, plays a role in the mediation of transport of potassium ions. 